Teguh Imam Sationo: Humanitarian Intervention Menurut....

\title{
HUMANITARIAN INTERVENTIONMENURUT HUKUM INTERNASIONAL DAN IMPLIKASINYA DALAM KONFLIK BERSENJATA
}

\author{
Teguh Imam Sationo \\ Fakultas Hukum Universitas Widya Mataram \\ Ndalem Mangkubumen KT III/237 Yogyakarta 55132, Indonesia \\ theisemha@yahoo.com
}

\begin{abstract}
Humanitarian intervention is an attempt to prevent or stop the gross human rights violations with particular strengths (diplomatic and military) in a State, either with or without the consent of the State (countries with internal conflict). The problems in this journal are: first, how the arrangement of international law on humanitarian intervention. Secondly, the role of the UN in humanitarian intervention in armed conflicts. The method used is a normative legal research methods with the main source of data collectionprocedures is a legal substance that contains of normative law. The results showed that the rules of international law on humanitarian intervention by the United Nations stipulated in the UN Charter and general principles of international law. Humanitarian intervention legally justified by following provisions in applicable international law, namely Articles 39-51 of UN Charter. While the role of the UN in humanitarian intervention in armed conflicts carried out by the Security Council as the organ of the United Nations in maintaining peace with the decision issued in the form of a resolution for areas experiencing conflict. Therefore, it takes an internationaltreaty that regulates clearly about humanitarian intervention, so that inpractice, remain consistent with the objectives and executive organs of humanitarian intervention.
\end{abstract}

Keywords: Humanitarian Intervention, Security Council of UN, Armed Conflict

\begin{abstract}
Abstrak
Intervensi kemanusiaan merupakan upaya untuk mencegah atau menghentikan pelanggaran HAM berat dengan kekuatan tertentu (diplomatic and military) di suatu negara, baik dengan atau tanpa persetujuan dari negara (countries with internal conflict). Masalah dalam jurnal ini adalah: pertama, bagaimana pengaturan hukum internasional tentang intervensi kemanusiaan. Kedua, bagaimana peran PBB dalam intervensi kemanusiaan dalam konflik bersenjata. Metode penelitian yang digunakan adalah metode penelitian hukum normatif dengan sumber utama prosedur pengumpulan data adalah bahan hukum yang berisi aturan-aturan hukum normatif. Hasil penelitian menunjukkan bahwa peraturan hukum internasional tentang intervensi kemanusiaan yang dilakukan oleh PBB diatur dalam Piagam PBB dan prinsip-prinsip umum hukum internasional. Intervensi kemanusiaan secara hukum dibenarkan dengan ketentuan berikut ketentuan yang diatur dalam hukum internasional yang berlaku, yaitu Piagam PBB Pasal 39-51. Sedangkan peran PBB dalam intervensi kemanusiaan dalam konflik bersenjata dilakukan oleh Dewan Keamanan sebagai organ PBB di menjaga perdamaian dengan mengeluarkan keputusan dalam bentuk resolusi untuk daerah-daerah yang mengalami konflik. Oleh karena itu, yang diperlukan suatu perjanjian internasional yang mengatur dengan jelas tentang intervensi kemanusiaan, sehingga dalam pelaksanaannya, tetap konsisten dengan tujuan dan organ eksekutif intervensi kemanusiaan.
\end{abstract}

Kata Kunci: Intervensi kemanusiaan, Dewan Keamanan PBB, Konflik Bersenjata 


\section{A. Pendahuluan}

Negara dalam hukum internasional dianggap sebagai subjek hukum utama. ${ }^{1}$ Dalam suatu hubungan antar subjek hukum internasional khususnya negara, sering terjadi pertentangan yang diakibatkan oleh perbedaan kepentingan. Dan tidak selamanya pertentangan tersebut dapat diselesaikan melalui penyelesaian damai. Pertentangan kepentingan inilah yang sering disebut dengan konflik. Konflik antar negara ini dapat disebabkan oleh beberapa faktor, seperti politik, ekonomi, ideologi, strategi militer, ataupun perpaduan antara kepentingan-kepentingan tersebut. ${ }^{2}$ Konflik dapat berupa konflik yang bersifat eksternal, yaitu yang terjadi antara negara dengan negara ataupun dapat berupa konflik yang bersifat internal yakni yang terjadi dalam suatu negara.

Penyelesaian konflik dapat digolongkan dalam dua kategori. Pertama, cara-cara penyelesaian damai, yaitu apabila para pihak dapat menyepakati untuk menemukan suatu solusi yang bersahabat. Kedua, cara-cara penyelesaian secara paksa atau dengan kekerasan, yaitu apabila solusi yang dipakai atau dikenakan adalah melalui kekerasan. ${ }^{3}$ Apabila negara-negara tidak dapat mencapai penyelesaian sengketa secara damai, satu-satunya pemecahan yang mungkin adalah melalui cara-cara kekerasan. Prinsipprinsip dari cara penyelesaian melalui kekerasan adalah perang dan tindakan bersenjata non perang, retorsi (retortion), tindakan-tindakan pembalasan (reprisals), blokade secara damai (pacific blockade), intervensi (intervention) ${ }^{4}$

Perang yang kemudian dikenal dengan istilah konflik bersenjata dalam perkembangannya bukan hanya antara negara dengan negara atau yang biasa dikenal dengan konflik bersenjata internasional, tetapi juga terjadi di dalam negara sendiri atau yang biasa dikenal dengan konflik non internasional. ${ }^{5}$ Melihat dalam konflik bersenjata sering disertai dengan genosida, kejahatan terhadap kemanusiaan dan

1 J.G. Starke, 1989, Pengantar Hukum Internasional I, Sinar Grafika, Jakarta, hlm. 12.

2 Sri Setianingsih Suwardi, 2006, Penyelesaian Sengketa Internasional, Penerbit Universitas Indonesia, Jakarta, hlm. 1.

3 J.G. Starke, 1989, Pengantar Hukum Internasional II, Sinar Grafika, Jakarta, hlm. 646.

${ }^{4}$ Ibid.

5 Konflik bersenjata dibedakan menjadi dua, yaitu konflik bersenjata internasional dan konflik bersenjata non internasional, Arlina permanasari dk, 1999, Pengantar Hukum Humaniter, Miamita Print ICRC, Jakarta, hlm. 129-139. 
kejahatan perang maka Sekretaris Jenderal (Sekjen) PBB Koffi Anan pada tahun 1998 mendesak agar masyarakat internasional menyepakati untuk melakukan intervensi terhadap negara (yang berkonflik) untuk menghentikan pelanggaran-pelanggaran berat terhadap HAM. Kesepakatan tersebut dibuat atas dasar prinsip-prinsip yang sah dan universal serta dalam kerangka hukum internasional untuk melindungi orangorang sipil dari pelanggaran besar-besaran HAM. ${ }^{6}$

Istilah intervensi mempunyai batasan sebagai suatu kegiatan yang dilakukan oleh suatu negara, kelompok dalam suatu negara, atau suatu organisasi internasional yang mencampuri secara paksa urusan dalam negeri negara lain.

Intervensi adalah campur tangan dari suatu negara terhadap masalah dalam negeri negara lain dengan tujuan untuk memelihara atau mengubah situasi yang ada. Salah satu bentuk intervensi dalam konflik bersenjata yang terjadi adalah konflik bersenjata yang terjadi di Rwanda dan Bosnia Herzegovina (bekas negara Yugoslavia). Sebagaimana diketahui di kedua negara tersebut telah terjadi konflik etnis. Pada awalnya konflik yang terjadi di kedua negara tersebut merupakan konflik bersenjata non internasional yang kemudian berubah menjadi konflik internasional karena adanya pihak-pihak negara lain yang ikut serta dalam kedua konflik tersebut.

Berdasarkan latar belakang tersebut di atas, untuk mengetahui dan memahami terhadap intervensi kemanusiaan yang berkembang saat ini, dikaji dan dianalisis secara mendalam agar dapat memberikan kejelasan pengaturan intervensi kemanusiaan dalam masyarakat internasional, untuk itu penulis ingin menyusun jurnal yang berjudul "Intervensi Kemanusiaan Menurut Hukum Internasional dan Implikasinya". Rumusan masalah dalam artikel ini yaitu, bagaimana pengaturan intervensi kemanusiaan dalam hukum dan bagaimana peran PBB dan ICRC dalam melaksanakan intervensi kemanusiaan pada konflik bersenjata.

${ }^{6}$ Basic Facts About the United Nations, 1998, New York, hlm. 72 sebagaimana dikutip dari Boer Mauna, 2011, Hukum Internasional Pengertian Peranan dan Fungsi dalam Era Dinamika Global, Alumni, Bandung, hlm. 647. 


\section{B. Metode Penelitian}

Metode Penelitian yang digunakan adalah metode penelitian hukum normatif dengan prosedur pengumpulan data yang sumber utamanya adalah bahan hukum yang berisi aturan-aturan yang bersifat hukum normatif. Data yang diperoleh dan diolah dalam penelitian hukum normatif adalah data sekunder yang berasal dari sumber kepustakaan. Studi kepustakaan dilakukan dengan cara mempelajari literatur, artikel, serta bahan bacaan lainnya yang berkaitan dengan penulisan artikel ini dilakukan melalui penelusuran kepustakaan ke perpustakaan Universitas Sebelas Maret Surakarta, Perpustakaan Daerah Propinsi Daerah Istimewa Yogyakarta, dan situs-situs internet yang berhubungan dengan penelitian ini

\section{Pembahasan}

\section{Pengaturan Intervensi Kemanusiaan menurut Hukum Internasional}

Intervensi (intervention) merupakan suatu tindakan yang dilakukan secara sengaja oleh suatu negara, sekelompok negara, ataupun agen internasional terhadap kebijakan atau praktek dari negara atau sekelompok negara lain di mana negara atau sekelompok negara yang dikenai tindakan tersebut tidak menyetujuinya. ${ }^{7}$ Intervensi juga dapat diartikan sebagai bentuk campur tangan diktatorial terhadap urusan dalam negeri suatu negara, yang mencakup penggunaan ancaman kekerasan atau pelemahan ekonomi secara substansial. $^{8}$

Beberapa analis menggunakan terminologi forcible atau pemaksaan, yang memiliki dua skala pengukuran. Skala rendah intervensi bisa diartikan sebagai tindakan mempengaruhi kebijakan domestik suatu negara, sedangkan skala tinggi adalah dengan melakukan tindakan koersif yang bisa berupa upaya-upaya militer. ${ }^{9}$ Walaupun demikian, intervensi tetap menjadi salah satu elemen dalam hubungan internasional dewasa ini, meskipun jelas sangat bertentangan dengan norma hukum dan moral.

${ }^{7}$ Coady, C.A.J. 2002. The ethics of armed humanitarian intervention. Washington: United States Institute of Peace. http://www.usip.org/sites/default/files/resources/pwks45.pdf. (Diakses pada 8 Desember 2017).

${ }^{8}$ Donnelly, J. 1983. Human Rights, Humanitarian Intervention, and American Foreign Policy. New York: Columbia University. p. 311.

${ }^{9}$ Nye, J. S. 2009. Understanding International Conflicts: An Introduction to Theory and History. New York: Pearson and Longman.p.166-167. 
Sementara, istilah bumanitarian merupakan istilah yang pada saat ini lazim digunakan untuk menunjukkan intervensi yang ditujukan untuk menyelamatkan warga negara asing dari bahaya yang sedang dilakukan, atau akan dilakukan, terhadap mereka oleh otoritas negara yang seharusnya melindungi mereka. Berdasarkan definisi tersebut, humanitarian intervention merujuk kepada suatu keadaan di mana suatu negara atau gabungan dari beberapa negara mengerahkan kekuatan militernya untuk membantu mengatasi pelanggaran hak asasi manusia berat yang terjadi di wilayah negara lain.

\section{Pro Kontra Intervensi Kemanusiaan}

Masalah intervensi kemanusiaan muncul dalam kasus-kasus di mana pemerintah sebuah negara sudah menggunakan kekuatan senjata terhadap rakyatnya sendiri, atau di mana sebuah negara telah kolaps dan hukum tidak berlaku lagi. ${ }^{10}$ Pelanggaran berat terhadap hak asasi manusia dewasa ini sudah berkembang menjadi masalah internasional, tetapi apakah legitimasi menggunakan kekuatan senjata untuk mencegah pelanggaran itu terjadi dibenarkan atau tidak, itu yang menjadi permasalahan. R.J. Vincent mengatakan apabila sebuah negara secara sistematis dan masif melanggar hak asasi manusia, masyarakat internasional mempunyai tugas untuk melakukan intervensi kemanusiaan. ${ }^{11}$

Kritik yang mempertanyakan tentang pelanggaran kedaulatan Libya dengan melakukan serangan dapat ditepis melalui pernyataan Koffi Annan: “... if bumanitarian intervention is, indeed, an unacceptable assault on sovereignty, how should we respond to a Rwanda, to a Srebrenica - to gross and systematic violations of human rights that offend every precept of our common bumanity? . ${ }^{12}$ Pernyataan tersebut dapat dipahami bahwa kemanusiaan merupakan prioritas utama yang seharusnya melandasi setiap operasi intervensi. Jika

10 Wheeler, N. J. 2000. Saving Strangers: Humanitarian Intervention in International Society. New York, Oxford University Press. p. 27.

${ }^{11}$ Vincent, R. J. 1986. Human Rights and International Relations. Cambridge: Cambridge University Press.p.127.

12 Guraizu, R. 2008. Is humanitarian military intervention in the affairs of another state ever justified? London: Middlesex University School of Health and Social Sciences. p.7. in http://archive.atlanticommunity.org/app/webroot/files/articlepdf/Is\%20humanitarian $\% 20$ military\% 20intervention $\% 20$ ever\%20justified.pdf $>$ diakses 8 Desember 2018 
tragedi kemanusiaan terjadi di suatu negara, maka sudah merupakan tanggung jawab dunia internasional untuk bergerak menghentikan kejadian tersebut.

Ini sejalan dengan prinsip Responsibility to Protect yang menyatakan bahwa "State sovereignty implies responsibility, and the primary responsibility for the protection of its people lies with the state itself, but, where a population is suffering serious harm, as a result of internal war, insurgency, repression or state failure, and the state in question is unwilling or unable to balt or avert it, the principle of non-intervention yields to the international responsibility to protect." Kedaulatan suatu negara berarti tanggung jawab untuk melindungi warganya dari kekerasan terhadap kemanusiaan. Apabila negara gagal memerankan tanggung jawab tersebut maka komunitas internasional-lah yang mengambil alih tanggung jawab tersebut. Pada saat tersebut, masalah kedaulatan negara bersangkutan dapat ditangguhkan sementara.

Di sisi lain, Hedley Bull menekankan pada bahaya yang ditimbulkan praktek tersebut pada ketertiban masyarakat dunia. Ia mengatakan bahwa negara-negara tidak memiliki hak untuk melakukan intervensi kemanusiaan karena ketidakinginan mereka untuk mengancam aturan kedaulatan negara lain dan prinsip non-intervensi, serta tidak mengakui hak untuk melakukan intervensi terhadap sebuah negara, oleh suatu negara. ${ }^{13}$ Pandangan ini diperkuat oleh konsep keamanan kolektif (collective security), di mana kumpulan negara-negara anggota (kolektif) berjanji untuk tidak menggunakan kekuatan senjata terhadap sesama anggotanya, kecuali jika salah satu anggota menyerang anggota lainnya terlebih dulu. Akan tetapi, konsep ini hanya berlaku pada negara-negara yang tergabung dalam aliansi, seperti dalam non-blok contohnya. NATO tidak dikategorikan masuk dalam keamanan kolektif karena dibuat sebagai tandingan Pakta Warsawa, alias ancamannya datang dari luar kolektif. ${ }^{14}$ Masalahnya, ketika NATO praktis tidak ada organisasi tandingan yang mampu menandinginya lagi, bolehkah sekarang ia menggunakan prinsip intervensi kemanusiaan pada siapapun yang dianggapnya berpotensi menentangnya.

Pada abad ke-19 pun, seorang John Stuart Mill bahwa kewajiban moral tertinggi dari masyarakat dunia adalah untuk menghormati hak untuk menentukan

\footnotetext{
${ }^{13}$ Bull, H. ed. 1984. Intervention in World Politics. Oxford, Oxford University Press.p.193

${ }^{14}$ Barash, D. P. dan Webel, C. P. 2009. Peace and Conflict Studies. California: Sage Publications.p.323.
} 
nasib sendiri. Komunitas politik harus menghargai prinsip self-government dari sebuah negara, karena dengan cara inilah mereka menyadari nilai-nilai kebebasan dan kebajikan. Pihak luar tidak boleh mengintervensi proses ini, karena menurut Mill melalui perjuangan yang sulit untuk merdeka dari sebuah negara, berdasarkan usaha mereka sendiri, maka nilai-nilai kebajikan tersebut akan muncul. ${ }^{15}$

Nicholas Wheeler mengatakan bahwa ada empat syarat di mana sebuah intervensi dianggap memiliki kualifikasi sebagai sebuah intervensi kemanusiaan. Pertama, harus karena adanya darurat kemanusiaan yang tinggi sifatnya. Kedua, penggunaan kekuatan senjata harus menjadi pilihan terakhir. Ketiga, harus memenuhi syarat proporsionalitas, dan keempat harus ada probabilitas tinggi yang menyatakan bahwa penggunaan kekuatan senjata akan memperoleh hasil kemanusiaan yang positif . $^{16}$

Prinsip ius ad bellum (hukum tentang keabsahan perang) harus diperhatikan juga di sini, karena prinsip ini menentukan sebuah perang dapat diterima atau tidak. Beberapa kriterianya adalah, pilihan terakhir; mempunyai kewenangan yang sah; tujuan yang benar dan just cause; kemungkinan keberhasilan besar; bertujuan akhir untuk perdamaian. Saat ini, dalam masyarakat internasional ius ad bellum telah berubah menjadi ius contra bellum (hukum yang melarang perang). Sebagaimana ditegaskan dalam Piagam PBB, setiap negara dilarang melakukan tindakan keras, kecuali sebagai pertahanan sendiri atau pertahanan bersama, tindakan penegakan dari Dewan Keamanan PBB, atau dalam rangka menegakkan hak rakyat untuk menentukan nasibnya (self-determination). Serupa halnya dengan hukum internasional, semua hukum nasional juga melarang warganya menggunakan tindakan keras terhadap pemerintah atau badan-badan penegak lainnya. ${ }^{17}$

Dalam praktiknya, belum ada satu kasus intervensi sekalipun sejak tahun 1945 yang memenuhi semua syarat-syarat ini, dan juga sangat tidak masuk akal untuk berpikir bahwa kasus-kasus intervensi di masa depan akan mampu memenuhi secara sempurna empat kriteria di atas. Seharusnya, masyarakat internasional melakukan

\footnotetext{
${ }^{15}$ Welsh, J. M, (ed.). 2004. Humanitarian Intervention and International Relations. Oxford: Oxford University Press.p.60.

${ }^{16}$ loc, cit, Wheeler, N. J. P.33-34

17 Ambarwati, Ramdhany, D. dan Rusman R. 2009. Hukum Humaniter Internasional Dalam Studi Hubungan Internasional. Jakarta: Rajawali Press. H1m. 48-49
} 
segala daya upaya, baik secara individu maupun kolektif, untuk mempengaruhi dan membujuk para pemimpin negara untuk hidup dalam etika solidaritas yang bertanggung jawab. Beberapa kasus intervensi yang sempat terjadi di Afrika pun, seperti di Somalia, Rwanda, dan Sierra Leone menghadapi hambatan struktural terhadap intractable conflict yang terjadi di sana. Daniel Bar-Tal banyak membahas isuisu terkait intractable conflict ini, terutama kasus Palestina dan Israel. ${ }^{18}$ Selain itu, faktor utama kegagalan memang karena kontradiksi-kontradiksi yang terjadi dalam pemahaman tentang konsepsi intervensi kemanusiaan itu sendiri.

Dalam Piagam PBB, larangan menyerang terhadap sebuah negara adalah sebuah prinsip yang sangat fundamental, dan tindakan bela diri terhadap serangan bersenjata adalah satu-satunya justifikasi yang paling jelas terhadap negara-negara yang menggunakan paksaan. Pasal 2 ayat 7 menjadi jaminan bahwa tidak ada upayaupaya mencampuri urusan dalam negeri sebuah negara. Seperti yang telah disebutkan, memang tahun sejak 1945 cukup banyak terjadi intervensi militer, yang terjadi dalam keadaan-keadaan tertentu, akan tetapi PBB secara rutin selalu mengutuk tindakan tersebut. $^{19}$

Negara yang berdaulat dapat mengadakan hubungan dengan anggota masyarakat internasional lainnya, maupun mengatur segala sesuatu yang ada atau terjadi di luar wilayah negara itu tetapi sepanjang ada kaitannya dengan kepentingan negara itu. Hal ini di dasari oleh Piagam PBB Pasal 2 ayat (1) yang menerangkan bahwa hubungan antar negara berdasarkan persamaan derajat dan bebas.

Hubungan internasional menurut Pasal 2 ayat (4) bahwa negara dalam elakukan hubungan internasional tidak boleh menggunakan kekerasan terhadap integritas wilayah atau kemerdekaan politik negara lain. Kemudian Pasal 2 ayat (7) Piagam PBB menyatakan bahwa setiap negara dalam melakukan hubungan internasional dilarang untuk melakukan suatu intervensi kedalam urusan domestik negara lainnya, begitu pula dengan PBB dilarang untuk ikut campur dalam urusan domestik negara lain dan mewajibkan negara-negara yang berkonflik untuk menyelesaikan urusannya menurut ketentuan Piagam PBB. Hal ini berkaitan dengan

\footnotetext{
18 Bar-Tal, D. 1998. "Societal beliefs in times of intractable conflict: the israeli case". International Journal of Conflict Management, 9(1).

${ }^{19}$ Roberts, A. 1993. Humanitarian war: military intervention and human rights. International Affairs, 69(3).p.431
} 
adanya prinsip non intervensi sebagai salah satu pondasi dasar dalam hukum internasional. $^{20}$

Prinsip non intervensi yang berkembang saat ini membuat kedaulatan negara saat ini tidak hanya dilihat sebagai hak negara, tetapi erat kaitannya dengan kewajiban negara untuk melakukan perlindungan hak asasi manusia.

Karena tujuan dibentuknya sebuah negara adalah untuk melindungi setiap manusia baik warga negaranya maupun warga negara asing dari terjadinya pelanggaran hak asasinya. Hanya saja seringkali dalam penerapannya, negara yang bersangkutan menyalahgunakan hak dan kewenangan yang dimiliki, bahkan sampai mengenyampingkan nilai-nilai kemanusiaan, yang kemudian mengakibatkan kesengsaraan kepada rakyatnya. Oleh karena itu, dalam keadaan banyaknya pelanggaran berat HAM yang terjadi, pihak asing dapat masuk sebagai pihak ketiga untuk menyelesaikan permasalahan yang terjadi dan mengembalikan kondisi negara tersebut kepada keadaan semula, salah satunya dengan cara intervensi.

Humanitarian intervention atau Intervensi kemanusiaan secara umum adalah upaya untuk mencegah atau menghentikan pelanggaran hak asasi manusia (HAM) berat dengan kekuatan-kekuatan tertentu (diplomatik dan militer) di suatu negara, baik dengan atau tanpa persetujuan negara itu (negara mengalami konflik internal). Ketika terjadi suatu masalah kemanusiaan di suatu negara yang bersifat pelanggaran hak asasi manusia yang berat, maka masyarakat internasional dibenarkan untuk melakukan suatu tindakan intervensi.

Pelanggaran hak asasi manusia berat ada berbagai macam seperti kejahatan kemanusiaan, genosida dan kejahatan perang, dan lainnya. Pengenalan kejahatan terhadap kemanusiaan (crimes against bumanity), pertama kali mulai dikenal dan telah menjadi hukum internasional positif yakni, setelah terjadi Perang Dunia II dalam Charter of International Military Tribunal Nuremberg (IMTN) tahun 1946, yang selanjutnya diatur dalam Charter of International Military Tribunal for The Far East (IMTFE) atau yang disebut juga dengan Piagam Tokyo pada tahun 1948, International Criminal Tribunal for Yugoslavia (ICTY) tahun 1993, International Criminal Tribunal for Rwanda (ICTR) tahun 1994, dan yang terakhir diatur dalam Statuta Mahkamah Pidana

\footnotetext{
20 Aidan Hehir, 2008, Humanitarian Intervention After Kosovo, England, Palgrave Mcmilan, hlm. 14 .
} 
Internasional (Statute for an International Criminal Court) yang kemudian lebih dikenal sebagai Statuta Roma pada tahun 2002.

Pengaturan tentang intervensi kemanusiaan belum diatur secara tegas dalam hukum internasional. Akan tetapi, menurut Piagam PBB Pasal 24 tentang tugas dan fungsi Dewan Keamanan PBB, maka PBB melalui Dewan Keamanan berhak menjalankan kewajibannya terkait adanya ancaman terhadap keamanan internasional, atau pelanggaran perdamaian dan keamanan, dan agresi sesuai dengan tujuan-tujuan dan prinsip-prinsip PBB dan dengan sebisa mungkin mengurangi penggunaan kekuatan bersenjata, hal ini sesuai dengan Pasal 26 Piagam PBB. ${ }^{21}$

PBB juga dalam menyelesaikan suatu konflik di dasarkan pada Bab VI Pasal 33 Piagam PBB. PBB memiliki mandat untuk melakukan semua upaya agar konflik dapat diselesaikan secara damai melalui cara-cara negoisasi, mediasi, arbitrasi, penyelesaian hukum, serta cara damai lainnya.

Selanjutnya Pasal 34 menyatakan bahwa PBB bisa melakukan investigasi setiap pertikaian (konflik) yang bisa membahayakan perdamaian internasional. Dewan Keamanan PBB dapat menyelidiki setiap pertikaian atau keadaan yang dapat menimbulkan ancaman terhadap perdamaian dan keamanan internasional.

Pada Pasal 36 Dewan keamanan dapat menganjurkan cara-cara penyelesaian yang dianggap sesuai dalam suatu pertikaian yang mengacu pada Pasal 33 atau suatu keadaan yang semacam itu. Selanjutnya Pasal 37 menerangkan bahwa apabila pihakpihak yang tersangkut dalam pertikaian tersebut dianggap tidak dapat menyelesaikan masalahnya, maka Dewan Keamanan akan menetapkan apakah akan diambil tindakan menurut Pasal 36 ataukah mengambil cara-cara penyelesaian yang dianggap layak.

Anjuran tentang cara-cara penyelesaian yang dianggap layak seperti yang tercantum dalam Bab VII Piagam PBB, Pasal 39 menyebutkan bahwa Dewan Keamanan akan menentukan ada tidaknya suatu ancaman terhadap perdamaian dunia dan akan menganjurkan atau memutuskan tindakan apa yang harus diambil sesuai dengan Pasal 41 Piagam PBB yaitu bahwa Dewan Keamanan dapat memutuskan tindakan apa yang dapat dilakukan di luar penggunaan kekuatan bersenjata, seperti

21 Michael N. Barnett, 2010, The International Humanitarian Order, New York, Routledge, hlm. 1. 
pemutusan hubungan ekonomi, alat-alat komunikasi, serta pemutusan hubungan diplomatik. Dan Pasal 42 yang menyatakan bahwa jika langkah-langkah politik dan ekonomi (berdasarkan Pasal 41) tidak bisa atau cukup mendorong pihak-pihak yang bertikai maka penggunaan kekuatan militer (kekuatan darat, laut, dan udara) dapat dibenarkan untuk menjamin kestabilan keamanan dan perdamaian internasional.Tindakan militer hanyalah langkah terakhir jika cara-cara lain tidak berhasil untuk melindungi penduduk dari pelanggaran HAM berat. Intervensi kemanusiaan yang dilakukan oleh PBB tidak melanggar kebebasan politik sebuah negara. Tindakan tersebut hanya bertujuan untuk memulihkan hak asasi manusia pada suatu negara yang mengalami konflik.

Setiap negara dan penduduknya tetap memiliki kebebasan politik. Atas asumsi ini intervensi kemanusiaan tidak melanggar Piagam PBB. Intervensi atas dasar kemanusiaan yang dikenal sebagai humanitarian intervention ini dilakukan secara kolektif berdasarkan mandat Perserikatan Bangsa-Bangsa dan bertujuan untuk mengatasi masalah kemanusiaan. Hal ini sesuai dengan Pasal 50 Piagam PBB yang mengatur salah satu bentuk intervensi. Di mana intervensi ini dilakukan dengan tujuan untuk menyelesaikan persoalan-persoalan yang ada. Selanjutnya intervensi dalam rangka pembelaan diri terdapat dalam Pasal 51 Piagam PBB.

\section{Langkah Lain Selain Intervensi}

Jalan kekerasan yang sebaiknya dihentikan, dan diganti dengan jalan damai seperti yang tertuang dalam Pasal 33 Piagam PBB. Berdasarkan pasal 33 penyelesaian dengan jalan damai meliputi negosiasi (perundingan) dan enquiry (penyelidikan). Kemudian konsiliasi (persetujuan) usaha ini diserahkan kepada panitia atau badan internasional yang ditunjuk oleh pihak-pihak dalam perselisihan untuk mengusulkan atas insiatif sendiri suatu persetujuan yang layak diterima oleh kedua belah pihak. Mediasi (perantara/jasa-jasa baik) dapat diselenggarakan oleh suatu negara, suatu komisi atau seorang tokoh saja, yang ditunjuk oleh pihak-pihak yang bersangkutan untuk mempermudah dan mempercepat tercapainya perdamaian. ${ }^{22}$ Selain itu, diatur pula cara-cara melalui jalur hukum seperti arbitration (perwasitan) pihak-pihak yang

${ }^{22}$ Kolb, R. dan Hyde, R. 2008. An Introduction to the International Law of Armed Conflicts. Portland: Hart Publishing, page. 175. 
bersangkutan berjanji terlebih dahulu, bahwa mereka akan menerima dan bersedia menjalankan keputusan seorang pendamai dari Mahkamah Arbitrasi. Serta keputusan kehakiman yang diambil oleh mahkamah Pengadilan Internasional. Sepantasnya caracara damai demikianlah yang dapat dijadikan solusi untuk mengatasi konflik di Libya.

Penggunaan preventive diplomacy adalah salah satu metode yang kita bisa gunakan untuk menegahi konflik Libya. Metode ini tidak dilakukan oleh pihak-pihak yang bersengketa, tetapi melalui keterlibatan pihak ketiga, khususnya di mana pihak-pihak yang berkonflik sendiri tidak mampu mencari jalan keluar dari konflik itu sendiri. Pihak ketiga ini bertugas untuk mengurangi intensitas konflik dan mendorong pihakpihak yang terlibat ke dalam meja perundingan untuk mencari solusi bersama. Untuk itu, pihak ketiga yang akan melakukan preventive diplomacy harus bersikap netral dengan tidak mendukung salah satu pihak yang bertikai. ${ }^{23}$ Preventive diplomacy umumnya diambil untuk mencegah sengketa atau perselisihan yang terjadi berkembang (eskalasi) menjadi konflik bersenjata. ${ }^{24}$ Dalam melakukan preventive diplomacy, cara-cara diplomatik menjadi sarana yang ditempuh untuk mempengaruhi pihak-pihak yang berkonflik untuk tidak menggunakan kekuatan senjata dan menggiring mereka ke arah negosiasi untuk penyelesaian damai bersama.

Preventive diplomacy dapat dilakukan oleh Sekjen PBB pribadi, melalui pejabat senior, badan-badan khusus atau program, oleh Dewan Keamanan maupun Majelis Umum dan oleh organisasi-organisasi regional bekerja sama dengan PBB. Preventive diplomacy memerlukan langkah-langkah untuk menciptakan kepercayaan; membuat satu peringatan dini dengan pengumpulan informasi dan misi pencari fakta baik resmi maupun tidak resmi; di samping juga harus melibatkan penempatan pasukan preventif; dan dalam keadaan tertentu menetapkan wilayah bebas militer. ${ }^{25}$ Diharapkan dengan langkah ini rakyat Libya dapat menikmati kehidupannya tanpa dibayang-bayangi dengan serangan-serangan bom yang mengakibatkan banyak korban yang bertentangan dengan HAM. Seyogyanya hal inilah yang sesuai dengan

${ }^{23}$ Wallensteen, P. 2012. Understanding Conflict Resolution. London, Sage Publications. Page 281-282

${ }^{24}$ The Point. 2011. Conflict prevention mechanisms: mediation and preventive diplomacy. (online) http://thepoint.gm/africa/gambia/article/conflict-prevention-mechanisms-mediation-andpreventive-diplomacy, diakses 8 Desember 2018.

${ }^{25}$ Suryokusumo, S. 2004. Praktik Diplomasi. Jakarta, BP Iblam. hlm. 148 
resolusi DK nomor 1973 yang menyerukan upaya gencatan senjata dan mengakhiri kekerasan serta semua serangan terhadap warga sipil

\section{Peran PBB dalam Melaksanakan Intervensi Kemanusiaan pada Konflik Bersenjata}

PBB merupakan organisasi yang paling besar selama ini dalam sejarah pertumbuhan kerja sama semua negara di dunia di dalam berbagai sektor kehidupan internasional. Menjaga perdamaian dan keamanan internasional erat kaitannya dengan prinsip kewajiban untuk melindungi (Responsibility to Protect) ${ }^{26}$ merupakan tanggung jawab semua negara untuk melindungi rakyatnya sendiri, serta tanggung jawab masyarakat internasional untuk membantu negara-negara mewujudkan hal tersebut. Bila suatu negara gagal melindungi rakyatnya, maka sejumlah cara, baik itu politik, ekonomi, maupun diplomatik akan digunakan untuk membantu negara tersebut. Hal ini dilakukan dengan menggunakan banyak cara termasuk negoisasi, mediasi, dan penerapan sanksi. Intervensi militer hanya mungkin digunakan sebagai upaya terakhir untuk menghentikan kekejaman massal yang dilakukan secara multilateral dengan persetujuan Dewan Keamanan. ${ }^{27}$

Bab VI dan Bab VII Piagam PBB menjelaskan tentang penyelesaian pertikaian secara damai dan tindakan-tindakan yang diperlukan untuk menjaga perdamaian internasional, dapat dilakukan dengan upaya sebagai berikut :

a. Dewan Keamanan PBB dan Majelis Umum bisa menunjuk misi pencari fakta (fact-finding mission) untuk menyelidiki dan melaporkan dugaan pelanggaran hukum internasional. Dewan HAM PBB juga dapat mengirim misi pencari fakta serta menunjuk perwakilan khusus atau pelapor khusus untuk memberikan saran mengenai situasi tertentu;

b. misi-misi tersebut dapat sekaligus memberikan peringatan dini tentang krisis kemanusiaan yang terjadi dan bernegosiasi dengan para pemimpin negara di mana krisis tersebut berlangsung untuk mencari cara penyelesaian;

26 ICISS, 2001, Responsibilty To Protect The Report, the International Development, Canada Research Centre, Page. 11-18.

27 Rahayu ,2012, Eksistensi Prinsip Responsibility to Protect dalam Hukum Internasional, MMH, No.1, Jilid 41, Januari 2012 dapat diakses http://ejournal.undip.ac.id/index.php/mmh/article/view/4212-9087-1-SM.pdf. 
c. pemutusan hubungan ekonomi, komunikasi, serta hubungan diplomatik apabila dalam perundingan tersebut tidak ditemukan penyelesaiannya; dan

d. pertimbangan PBB untuk menggunakan kekuatan militer guna menghadapi kekerasan massal yang mendesak dan bersifat aktual. Hal penting yang harus diingat bahwa penggunaan kekuatan militer ini harus merupakan upaya terakhir bila suatu negara dipandang gagal melindungi warganya dan bila caracara damai yang ditempuh juga mengalami kegagalan.

Intervensi kemanusiaan sering disorot atas legitimasinya. Oleh karena itu, sebagian pakar hukum internasional berpendapat bahwa intervensi kemanusiaan tetap bisa dilakukan selama memenuhi persyaratan sebagai berikut: ${ }^{28}$

a. intervensi kemanusiaan harus di dasarkan atas alasan dan tujuan yang jelas, yaitu untuk melindungi hak asasi manusia;

b. harus dilakukan dengan memperhatikan syarat proporsionalitas, dan tidak eksesif; dan

c. harus di dasarkan aturan yang jelas untuk menghindari terjadinya eksploitasi oleh satu negara terhadap wilayah yang didudukinya.

Ketentuan yang terdapat dalam Bab VII Piagam PBB merupakan legitimasi dari intervensi kolektif terhadap suatu wilayah negara oleh PBB. Babkan dengan tegas Sekjen PBB sebelumnya, Koffi Annan mengatakan babwa: "Our job is to intervene: to prevent conflict where we can, to put a stop to it when it has broken out, or when neither of those things is possible - at least to contain it and prevent it from spreading". ${ }^{29}$

Salah satu bentuk intervensi dalam konflik bersenjata yang terjadi adalah konflik bersenjata yang terjadi di Rwanda dan Bosnia Herzegovina (bekas negara Yugoslavia). Bosnia adalah pecahan dari negara federal Yugoslavia. Negara ini mempunyai catatan konflik berkepanjangan. ${ }^{30}$ Sejak Serbia dipimpin oleh Slobodan Milosevic terjadi kerusuhan etnis, kerusuhan etnis memuncak ketika disahkannya amandemen undang undang dasar Republik Serbia, yang menyatakan bahwa otonomi Kosovo berada di bawah pengawasan pemerintah Republik Serbia (Maret 1989).

28 Idris, et.al., 2012, Penemuan Hukum Nasioanal dan Internasional, Fikahati Aneska, Bandung, , hlm. 295; lihat dalam Imam Mulyana, Doktrin Intervensi dalam Piagam PBB dan Perkembangannya Dewasa Ini.

${ }^{29}$ Idris, et.al., Op.Cit., hlm. 286.

${ }^{30}$ Ibid. 
Dengan adanya keinginan etnis Albania untuk merdeka dan menjadikan Republik Kosovo sebagai negara yang berdaulat terpisah dari Serbia maka menimbulkan aksi agresif Slobodan Milosevic menumpas gerilyawan dan mengusir etnik Albania dari Kosovo, Milosevic menggelar KLA (Tentara Pembebasan Kosovo) untuk memberantas kelompok separatis yang mengupayakan kemerdekaan Kosovo. Sedangkan Serbia berpendapat Kosovo secara historis berada dalam kawasan dan sebagai bagian Serbia, dan bagi mereka UCK adalah kelompok teroris yang harus dihancurkan.

Dengan adanya aksi brutal tersebut, mengakibatkan banyak korban berjatuhan dari warga sipil Albania. ${ }^{31}$

Di samping mengacu kepada sejumlah landasan moral, intervensi yang dilakukan oleh PBB dalam konflik Yugoslavia dibentuk berdasarkan resolusi PBB. Seperti salah satu bentuk dari resolusi tersebut ialah dibentuk Mahkamah Kejahatan Internasional, International Criminal Tribunal for Former Yugoslavia yang dibentuk berdasarkan Resolusi Dewan Keamanan PBB No. 827 pada tahun 1993 dan International Criminal Tribunal for Rwanda dibentuk berdasarkan Resolusi Dewan Keamanan No. 955 pada tahun 1994. PBB juga memberikan andil dengan mengeluarkan Resolusi Dewan Keamanan PBB 1244 pada 10 Juni 1999 menerangkan bahwa Kosovo ditempatkan di bawah administrasi PBB dengan tugas membentuk pemerintahan sementara untuk Kosovo, agar rakyat Kosovo mendapat otonomi luas dan pemerintahan sendiri. ${ }^{32}$

Pada kasus di Rwanda yang terjadi adalah konflik etnis yang antara suku Hutu dan Tutsi yang memakan korban jiwa dari pihak sipil. Sejak meletusnya perang antara pemerintah dengan pemberontak Front Patriotik Rwanda (FPR) di bulan Oktober 1990, telah dilakukan sejumlah upaya perdamaian dengan melibatkan sejumlah negara dikawasan itu. ${ }^{33}$

Kesepakatan damai tersebut menjelaskan bahwa PBB akan memainkan peranan besar melalui pasukan internasional yang netral (The Neutral National

31 Peran PBB dalam Usaha Pencapaian Kemerdekaan Kososvo dapat diakses pada http://publikasi.umy.ac.id/files/journals/8/articles/1918/public/1918-2337-1-PB.pdf.

32 Peran PBB dalam Usaha Pencapaian Kemerdekaan Kososvo, Loc.cit.

33 http://www.library.upnvj.ac.id/pdf/5FISIPS1IK/207613003/BAB\%20III.pdf diakses pada tanggal 5 Desember 2018 pukul 23.46. 
Forces-NIF). Pasukan ini bertugas mengawasi dan membantu implementasi perjanjian tersebut selama periode transisi yang akan berlangsung dalam kurun waktu 22 bulan. $^{34}$

Berdasarkan rekomendasi dari misi tersebut, intervensi pasukan PBB akan dilakukan dalam empat tahapan. Tahap pertama, pengiriman tim yang terdiri dari 25 personil militer, 18 personil sipil, dan 3 polisi sipil setelah mendapat otorisasi formal dari Dewan Keamanan PBB. Misi ini akan berlangsung 90 hari dengan tugas mengamankan Kigali dan menciptakan kondisi yang diperlukan bagi pembentukan pemerintahan transisi. Tahap kedua, akan memakan waktu 90 hari dengan tugas utama demobilisasi dan integrasi angkatan bersenjata dan polisi nasional (Gendamerie). Pada tahap ketiga, memakan waktu sembilan bulan, integrasi angkatan bersenjata Rwanda akan dituntaskan dan kekuatannya dikurangi menjadi 1.240 personil. Pada tahap terakhir yang akan berlangsung selama empat bulan, misi PBB akan dikurangi menjadi berkekuatan 930 personil militer dengan tugas membantu mengamankan iklim yang diperlukan dalam tahapan akhir sampai dengan dilaksanakannya pemilu. ${ }^{35}$

Berdasarkan asas kemanusiaan bahwa manusia memiliki hak yang sama untuk hidup yang merupakan landasan moral untuk dilaksanakannya intervensi, PBB juga melaksanakan intervensi dalam konflik di Rwanda ini juga dapat dibenarkan dengan mengacu pada Bab VI, Bab VII, Pasal 55 dari Piagam PBB dan adanya sejumlah resolusi dan mandat Dewan Keamanan PBB. Selama kurun waktu antara Oktober 1993 sampai dengan Juli 1994, Dewan Keamanan PBB telah mengeluarkan sejumlah resolusi dan mandat terkait dengan konflik di negara tersebut. ${ }^{36}$ Berdasarkan Resolusi Nomor 812 PBB akan mendukung upaya untuk menjaga perdamaian dan keamanan di wilayah Rwanda khususnya untuk mencegah terjadinya konflik kembali.

Kemudian PBB membentuk the United Nations Observer Mission UgandaRwanda (UNOMOR) melalui Resolusi Nomor 846 untuk memeriksa keadaan

\footnotetext{
${ }^{34} \mathrm{Ibid}$.

${ }^{35}$ Ibid.

${ }^{36}$ Ibid.
} 
disana selama enam bulan. Setelah itu melalui Resolusi $872^{37}$, Dewan Keamanan PBB secara bulat membentuk UNAMIR, pasukan peace keeping berkekuatan 2.500 personil untuk memelihara perdamaian di Rwanda.

Pasukan penjaga perdamaian di Rwanda tersebut setidaknya dapat membantu memulihkan keadaan dan mengurangi jatuhnya korban jiwa kembali. Karena tujuan dari diadakannya intervensi kemanusiaan adalah meminimalisir kekerasan yang terjadi dan mencoba membuat proses perdamaian dan keamanan berlangsung. Apabila kekerasan terus berlangsung, maka jalan satu-satunya adalah meminimalisir korban yang jatuh dengan jalan menyelamatkan pihak yang lemah, biasanya dari kalangan penduduk sipil. Penyerangan terhadap penduduk sipil nonkombatan dapat menyeret pelakunya ke Mahkamah Internasional kejahatan perang untuk diadili.

\section{Intervensi Kemanusiaan ICRC terhadap korban konflik di Suriah}

Dalam pencegahan konflik bersenjata, peran utama ICRC adalah mendesak pemerintah pusat untuk mengambil tindakan yang diperlukan, dan pada saat yang tepat, memberikan informasi yang relevan dan analisis untuk membantu menentukan tanggung jawabnya secara obyektif. Karena batasan ketat prinsip netralitas, ICRC tidak dapat memainkan peran dalam negosiasi politik untuk menghindari konflik bersenjata. Akan tetapi, ICRC kadang-kadang bisa berperan sebagai regulator dan untuk memainkan peran netral, melalui diplomasi pencegahan kemanusiaan, untuk memberikan kontribusi yang cukup besar.

Hal ini juga diadopsi pada saat Konferensi Palang Merah dan Bulan Sabit Merah Internasional di Wina tahun 1965 melalui Resolusi ke-20. Resolusi itu mendorong ICRC untuk bekerja sama penuh dengan PBB dalam rangka misi kemanusiaan. Setiap upaya yang mereka laksanakan harus dilakukan untuk mencegah atau menghentikan konflik bersenjata. ICRC juga harus memperoleh

37 S/RES/872 "Decides to establish a peace-keeping operation under the name "United Nations Assistance Mission for Rwanda" (UNAMIR) for a period of six months subject to the proviso that it will be extended beyond the initial ninety days only upon a review by the Council based on a report from the Secretary-General as to whether or not substantive progress has been made towards the implementation of the Arusha Peace Agreement". 
persetujuan dari negara, bersama-sama untuk mengambil langkah-langkah yang sesuai dalam mengakhiri konflik bersenjata, namun ICRC tidak bisa mengambil inisiatif yang dapat menyebabkan konflik bersenjata, namun untuk melindungi perilaku korban, atau mengambil inisiatif untuk mengambil apa pun yang mungkin membuat perwakilan atau staf menjadi tindakan berbahaya. Dengan menghabiskan dana sebanyak 15.867 KCHF atau sekitar 187.132.900 rupiah, semua kegiatan di atas dilaksanakan oleh ICRC selama lima bulan sejak dimulainya konflik pada tanggal 5 November sampai akhir Desember 2011

Sejak konflik pecah pada maret 2011, Suriah mengalami krisis kemanusiaan yang menyebabkan semakin terpuruknya keberadaan Hak Asasi Manusia di negara tersebut. Ketidakstabilan hukum di Suriah dan pelanggaran HAM seperti pengeboman yang terjadi terhadap warga sipil memiliki dampak terhadap struktur sosial mereka. Perempuan dan anak-anak menghadapi banyak ancaman dan kekerasan dalam situasi konflik bersenjata di Suriah. ICRC meyatakan perempuan merupakan yang paling parah terkena dampak dari terjadinya konflik di Suriah, bahwa sekitar 5,1 juta perempuan telah menjadi korban dalam konflik tersebut. Kondisi dan situasi yang dialami oleh perempuan di Suriah sangat memperihatinkan.

Perempuan tidak luput dari korban pembunuhan oleh pasukan militer dikarenakan perempuan yang paling sering menjadi target serangan langsung bahkan pembunuhan yang disengaja. Dalam laporan ICRC pada tahun 2013, kematian perempuan telah mencapai 9\% dari jumlah total korban dalam perang. Pembunuhan ini terjadi terutama karena penembakan terhadap warga sipil, baik dengan menggunakan barel peledak, peluncuran rudal hingga penembakan yang sengaja dilakukan oleh pasukan militer.

Tingkat kekerasan terhadap perempuan di Suriah terus meningkat. Kebanyakan dari perempuan Suriah menjadi korban kekerasan berbasis gender. Bentuk-bentuk dari kekerasan tersebut adalah kekerasan seksual: pemerkosaan dan kehamilan paksa, penyiksaan, dan perbudakan, baik oleh tentara pemerintah maupun kelompok-kelompok bersenjata.

Dalam laporan ICRC pada tahun 2013, sedikitnya kasus pemerkosaan telah mencapai 6000 kasus yang juga mengakibatkan meningkatnya kasus 
kehamilan paksa. Beberapa kasus kekerasan seksual yang terjadi di Homs, Damaskus, Hama, Latakia, Daraa, Idlib dan Tartous, menunjukkan bahwa terdapat tiga situasi utama di mana insiden pemerkosaan terjadi. Pertama, saat penggerebekan yang dilakukan oleh militer. Kedua, di pos pemeriksaan dan yang terakhir dalam fasilitas penahanan. Hal ini menunjukkan bahwa anggota aparat keamanan negara telah terlibat dalam kekerasan seksual. Pada tahun 2014, kekerasan seksual semakin meningkat, terutama yang dilakukan oleh kelompok teroris. Pelecehan terhadap perempuan juga seringkali digunakan sebagai taktik yang disengaja untuk mengalahkan pihak lain dari segi simbolis maupun psikologis. Hal lain yang turut dialami perempuan Suriah adalah trauma akibat perang. Konflik Suriah menunjukkan bagaimana seringnya perempuan menjadi obyek kekerasan selama perang berlangsung.

Selain perempuan, anak-anak juga seringkali menjadi korban dalam konflik bersenjata. Kondisi konflik bagi anak-anak seringkali menjadikan anak-anak kelompok yang rentan mengalami kekerasan karena posisi mereka sebagai pihak yang tidak terlindungi yang disebabkan oleh implikasi negatif dari konflik tersebut. konflik Suriah berdampak signifikan terhadap kesejahteraan emosional dan sosial dan perkembangan anak-anak.

Dalam konflik anak-anak tidak bisa mengandalkan orang tua mereka untuk mendapatkan perlindungan karena banyak diantara mereka yang anggota keluarganya tewas dalam konflik. Sehingga penyerangan dan kekerasan seksual juga kerap kali terjadi terhadap anak-anak Suriah yang seringkali digunakan sebagai senjata psikologis. Selain itu kebanyakan anak-anak yang kehilangan keluarganya dipaksa bergabung dengan milisi ataupun pemberontak bersenjata dan terlibat pula dalam peperangan, bukan sebagai target, melainkan sebagai combatant. Sehingga anak-anak yang terindoktrinasi dengan kekerasan tersebut akan lebih rentan terlibat dalam aksi-aksi terorisme. Menurut data yang diterima oleh PBB sekitar 11.420 anak-anak di Suriah terbunuh dalam konflik tersebut dan Sekitar 2,8 juta anak-anak di kota di Homs, Damaskus, Hama, Latakia, dan Daraa, masih berada di zona perang. Akibat dari perang Suriah anak-anak juga menghadapi masalah tekanan mental dan psikologis yang begitu besar. Bahkan, sebagian dari mereka harus hidup cacat disebabkan oleh perang. Pada tahun 2015, UNICEF 
mengidentifikasi 1.500 kasus pelanggaran berat hak-hak anak di Suriah, diantaranya lebih dari 60\% kasus pembunuhan dan penganiayaan menyusul penggunaan senjata peledak di wilayah sipil yang berpenghuni yang dilakukan oleh tentara-tentara Suriah.

PBB juga mengungkapkan bahwa selain menahan dan menyiksa anak-anak tentara Suriah juga menyerang sistem pendidikan karena kelompok bersenjata cenderung melihat sasaran sekolah dan anak-anak sekolah. Dengan melihat semakin meluasnya konflik di Suriah yang menyebabkan semakin banyaknya korban yang di dominasi oleh perempuan dan anak-anak maka ICRC membuat program kemanusiaan khusus untuk menangani perempuan dan anak-anak yang terkena dampak dari konflik Suriah, dimana dalam program ini ICRC melibatkan organisasi kemanusiaan lain yang berada di Suriah seperti SARC, UNICEF, Women for Women dan LSM-LSM lainnya yang ada di Suriah. Dimana dalam program ini pencegahan dan respon pencegahan mempertimbangkan sesuai dengan aturan intervensi kemanusiaan dan mencoba memprioritaskan pemprograman yang sesuai dengan kondisi konflik yang terjadi di Suriah.

\section{Penutup}

Berdasarkan pembahasan dan penguraian fakta yang telah dilakukan sebelumnya, dapat ditarik kesimpulan sebagai berikut :

a. Instrumen hukum internasional menyebutkan secara eksplisit bahwa prinsip nonintervensi merupakan salah satu prinsip fundamental dalam hukum internasional. Hal tersebut dapat dilihat dalam Pasal 1 (1), 2 (4), (7) Piagam PBB. Akan tetapi, Intervensi kemanusiaan tidak melanggar kebebasan politik sebuah negara. Tindakan tersebut hanya bertujuan untuk memulihkan hak asasi manusia pada suatu negara. Setiap negara dan penduduknya tetap memiliki kebebasan politik. Pengaturan intervensi kemanusiaan terdapat dalam Piagam PBB yang diatur dalam Pasal 2 ayat (4), Pasal 24, Pasal 25, Pasal 26, Pasal 33, Pasal 34, Pasal 39, Pasal 40, Pasal 49, Pasal 50, dan Pasal 51. Selain itu, intervensi juga mendapatkan legitimasinya berdasarkan prinsipprinsip umum seperti prinsip kemanusiaan dan prinsip hukum HAM yaitu prinsip kesetaraan; dan 
b. Intervensi kemanusiaan dapat dilakukan oleh PBB melalui Dewan Keamanan. Dewan Keamanan melakukan intervensi kemanusiaan melalui tahap pencarian fakta-fakta, diplomasi, dan penggunaan militer. Dewan Keamanan menunjuk misi pencari fakta untuk menyelidiki dan melaporkan dugaan pelanggaran hukum internasional, misi-misi tersebut dapat sekaligus memberikan peringatan dini tentang krisis kemanusiaan yang terjadi dan bernegosiasi dengan para pemimpin negara di mana krisis tersebut berlangsung untuk mencari cara penyelesaian, dan upaya penggunaan kekuatan militer guna menghadapi kekerasan massal yang mendesak dan bersifat aktual. Penggunaan kekuatan militer ini harus merupakan upaya terakhir bila suatu negara dipandang gagal melindungi warganya dan bila caracara damai yang ditempuh juga mengalami kegagalan.

ICRC hadir mengintervensi konflik tersebut dengan melakukan tugasnya sebagai organisasi yang menjunjung tinggi netralitas dan kemandirian, sehingga tidak akan menimbulkan provokasi bahkan dapat membantu untuk menangani masalahmasalah kemanusiaan, seperti tiga hal yang dilakukan oleh pihak ICRC yaitu dukungan untuk kebijakan nasional, membangun kapasitas kelembagaan dan sistem untuk perlindungan terhadap semua warga sipil khususnya perempuan dan anakanak, dan Meningkatkan Pengetahuan dan Pemahaman tentang Masalah Perlindungan Hak Asasi Manusia dan khususnya perempuan di Suriah. Intervensi kemanusiaan yang dilakukan oleh ICRC berlandaskan Hukum Humaniter Internasional (HHI) serta atas nama perlindungan HAM. 


\section{DAFTAR PUSTAKA}

\section{Buku}

Ambarwati, Ramdhany, D. dan Rusman R. 2009. Hukum Humaniter Internasional Dalam Studi Hubungan Internasional. Jakarta: Rajawali Press

Barash, D. P. dan Webel, C. P. 2009. Peace and Conflict Studies. California: Sage Publications.

Barnett, Michael, 2010. The International Humanitarian Order, New York, Routledge.

Bull, H. ed. 1984. Intervention in World Politics. Oxford: Oxford University Press.

Donnelly, J. 1983. Human Rights, Humanitarian Intervention, and American Foreign Policy. New York, Columbia University

Hehir, Aidan, 2008. Humanitarian Intervention After Kosovo, England, Palgrave Mcmilan.

ICISS, 2001. Responsibilty To Protect The Report, Canada: the International Development Research Centre.

Idris (ed), 2012. Penemuan Hukum Nasional dan Internasional, Bandung, Fikahati Aneska.

Kolb, R. dan Hyde, R. 2008. An Introduction to the International Law of Armed Conflicts. Portland: Hart Publishing

Nye, J. S. 2009. Understanding International Conflicts: An Introduction to Theory and History. New York: Pearson and Longman.

Mauna, Boer, 2011. Hukum Internasional Pengertian Peranan dan Fungsi dalam Era Dinamika Global, Bandung, Alumni.

Permanasari, Arlina, dkk, 2000. Pengantar Hukum Humaniter, Jakarta, Miamita Print ICRC.

Roberts, A. 1993. Humanitarian war: military intervention and buman rights. International Affairs, 69(3)

Starke, J,G., 1989. Pengantar Hukum Internasional I, Jakarta, Sinar Grafika. , 1989. Pengantar Hukum Internasional II, Jakarta, Sinar Grafika.

Suryokusumo, S. 2004. Praktik Diplomasi. Jakarta, BP Iblam.

Suwardi, Sri Setianingsih, 2006. Pengantar Hukum Organisasi Internasional, Jakarta: UI Press.

Vincent, R. J. 1986. Human Rights and International Relations. Cambridge: Cambridge University Press. 
Welsh, J. M, (ed.). 2004. Humanitarian Intervention and International Relations. Oxford: Oxford University Press.

Wheeler, N. J. 2000. Saving Strangers: Humanitarian Intervention in International Society. New York: Oxford University Press.

\section{Jurnal, Artikel, Makalah, dan Sumber Internet lainnya}

Bar-Tal, D. 1998. "Societal beliefs in times of intractable conflict: the israeli case". International Journal of Conflict Management, 9(1).

Coady, C.A.J. 2002. The ethics of armed humanitarian intervention. Washington, United States Institute of Peace. In http://www.usip.org/sites/default/ files/resources/pwks45.pdf.

Guraizu, R. 2008. Is humanitarian military intervention in the affairs of another state ever justified? London: Middlesex University School of Health and Social Sciences.. $<$ http://archive.atlantic-

community.org/app/webroot/files/articlepdf/Is $\% 20$ humanitarian $\% 20$ military $\% 20$ intervention $\% 20$ ever $\% 20$ justified.pdf $>$

http://www.library.upnvj.ac.id/pdf/5FISIPS1IK/207613003/BAB\%20III.pdf.

http://www.un.org/en/sc/documents/resolutions/1994.shtml.

https://www.google.com/\#q=resolusi $+\mathrm{dk}+\mathrm{pbb}+$ no+743+tahun+19 92.

http://ejournal.undip.ac.id/index.php/mmh/article/view/4212-9087-1-SM.pdf.

Peran PBB dalam Usaha Pencapaian Kemerdekaan Kososvo dapat diakses pada http://publikasi.umy.ac.id/files/journals/8/articles/1918/public/1918-23371-B.pdf.

Rahayu, Eksistensi Prinsip Responsibility to Protect dalam Hukum Internasional, MMH, No.1, Jilid 41, Januari 2012 dapat diakses Fiat Justisia Jurnal Ilmu Hukum Volume 8 No. 4, Oktober-Desember 2014. ISSN 1978-5186641

The Point. 2011. Conflict prevention mechanisms: mediation and preventive diplomacy. (online). http://thepoint.gm/africa/gambia/article/conflictprevention-mechanisms-mediation-and-preventive-diplomacy.

\section{Dokumen}

United Nations Charter (Piagam PBB).

United Nations Security Council Resolution S/RES/827 (1993), on the establishment of an international tribunal for the Former Yugoslavia, (tentang pembentukan Pengadilan Internasional untuk penjahat Negara bekas Yugoslavia).

United Nations Security Council Resolution S/RES/812 (1993), the contribution of United Nations might assist the process towards political settlement in Rwanda, (upaya PBB untuk menjaga perdamaian di Rwanda).

United Nations Security Council Resolution S/RES/846 (1993), on the establishment of the United Nations Observer Mission Uganda-Rwanda (UNOMOR) (tentang pembentukan UNOMOR).

United Nations Security Council Resolution S/RES/872 (1993), on the establishment of the UN Assistance Mission for Rwanda (tentang pembentukan UNAMIR). 
United Nations Security Council Resolution S/RES/955 (1994), on the establishment of an international tribunal for Rwanda and the adoption of the statute of the tribunal (tentang pembentukan International Criminal Tribunal for Rwanda).

United Nations Security Council Resolution S/RES/1244 (1999) on the situation relating Kosovo (tentang pemerintahan kosovo dibawah naungan $\mathrm{PBB}$ ). 